\title{
Antiproliferative and Cytotoxic Efficacy of 10-Hydroxy-2-Decenoic Acid, Compared to Doxorubicin, on MCF-7 Breast Cancer Cells
}

\author{
Wantha Jenkhetkan ${ }^{1}$, Arunporn Itharat ${ }^{2}$, Supranee Kongkham ${ }^{3}$, \\ Srisopa Ruangnoo ${ }^{2}$ and Treetip Ratanavalachai, ${ }^{3, *}$ \\ ${ }^{I}$ Division of Biochemistry and Molecular Biology, Faculty of Medicine, Thammasat University, \\ Pathumthani 12120, Thailand \\ ${ }^{2}$ Department of Thai Traditional Medicine, Faculty of Medicine, Thammasat University, \\ Pathumthani 12120, Thailand \\ ${ }^{3}$ Department of Preclinical Sciences, Division of Biochemistry, Faculty of Medicine, \\ Thammasat University, Pathumthani 12120, Thailand
}

("Corresponding author's e-mail: treetip2000@gmail.com)

Received: 1 January 2021, Revised: 30 April 2021, Accepted: 1 May 2021

\begin{abstract}
Exploration of effective chemotherapy is needed for cancer treatment. 10-hydroxy-2-decenoic acid (10-H2DA), a unique fatty acid from royal jelly (RJ), is reported to have antitumor activities. However, its mechanisms remain under-examined. This study investigated the antiproliferative and cytotoxic efficacy of 10-H2DA treatments and their underlying mechanisms, compared to doxorubicin (DXR), on MCF-7 breast cancer cells. The antiproliferative effect was determined using the MTS tetrazolium assay. Cytotoxic activity was performed using a modified MTS assay. Cell cycle progression and cell apoptosis were analyzed by flow cytometry. Pivotal protein expressions were detected by Western blot. Results revealed that $125 \mu \mathrm{g} / \mathrm{mL} 10-\mathrm{H} 2 \mathrm{DA}$ treatment significantly inhibited cancer cell growth by $65 \%$, better than $0.54 \mu \mathrm{g} / \mathrm{mL}$ DXR treatment $(48 \%)$, compared to the medium control $(\mathrm{p}<0.05)$. The $50 \%$ lethal concentration $\left(\mathrm{LC}_{50}\right)$ values of $10-\mathrm{H} 2 \mathrm{DA}$ were $190 \mu \mathrm{g} / \mathrm{mL}$, representing cytotoxic activity. The underlying antiproliferative and cytotoxic mechanisms of $125 \mu \mathrm{g} / \mathrm{mL}$ 10-H2DA treatment demonstrated that it extensively suppressed c-MYC/BAX and slightly activated p53/BAX, leading to G0/G1 cell cycle arrest (decreased cyclin D1 and CDK4) and cell apoptosis (decreased BCL2/BAX). It slightly limited lifespan extension (decreased hTERT/BAX). Nevertheless, it strongly activated HO-1/BAX and NRF2/BAX, possibly inducing chemoresistance and cell invasion later on. Our findings suggested that 10-H2DA treatments induced antiproliferative effects on MCF-7 breast cancer cells via suppression of cMYC, CDK4, and cyclin D1, leading to cell cycle arrest and cell apoptosis. However, long-term treatment may increase chemoresistance and cell invasion due to induction of antioxidative power, NRF2/BAX, and HO-1/BAX. Therefore, aggressive treatment for a short period would be recommended for using 10-H2DA as a chemotherapeutic compound to prevent chemoresistance and cell invasion. Further long-term in vitro and in vivo studies are necessary to confirm its strength and weakness.
\end{abstract}

Keywords: Apoptosis, Cell cycle arrest, C-MYC, 10-hydroxy-2-decenoic acid, NRF2, HO-1

\section{Introduction}

Breast cancer is the most common cancer and the leading cause of cancer death in women worldwide [1]. Cancer can be characterized by the uncontrolled growth of abnormal cells to produce cell populations that can invade or metastasize. Activation of oncogenes, suppression of tumor suppressor genes, ability to evade apoptosis, extending lifespan, and inducing blood vessel formation or angiogenesis provide a selective advantage for cancer cell survival. These are the hallmarks of cancer [2]. Various chemotherapeutics acting on these mechanisms have been used, but they have some limitations due to their potency, side effects, and chemoresistance [3]. New medicinal products are needed to be explored for more effective treatment.

Royal jelly (RJ), a natural product from bees, contains nutritious substances rich in vitamin B, minerals, proteins, fatty acids, and polyphenols. RJ and its principal fatty acid, 10-hydroxy-2-decenoic acid (10-H2DA), have been reported to possess various pharmacological activities, e.g., antitumor [4], 
antibacterial [5], anti-inflammatory [6], and lifespan extension [7]. RJ and 10-H2DA completely inhibited the tumor development of transplantable leukemia and ascites tumor cells in mice when premixed with tumor cells $[4,8]$. Oral intake of RJ improved anti-cancer effects and suppressed adverse events of molecular targeted therapy in renal cell carcinoma patients via decreased tumor necrosis factor (TNF)- $\alpha$ and transforming growth factor (TGF)- $\beta$ [9]. 10-H2DA has been reported to inhibit VEGF-induced angiogenesis, tumor cell invasion, and metastasis in chemo-resistant breast cancer cells [10]. Nevertheless, it has been reported that 10-H2DA did not inhibit bisphenol A-induced proliferation of MCF-7 breast cancer cells, but RJ did [11]. Hence, more studies on antitumor activities and mechanisms of 10-H2DA are still needed to assure its efficacy. The present study aimed to investigate the antiproliferative and cytotoxic efficacy and underlying molecular mechanisms of 10-H2DA, compared to doxorubicin, on MCF-7 breast cancer cells. Doxorubicin (DXR), a potent breast cancer chemotherapeutic drug, is used as a positive control. It inhibits DNA topoisomerase II and also generates free radicals to kill cancer cells [12].

To elucidate the molecular mechanisms of 10-H2DA and DXR, pivotal regulatory protein expressions (C-MYC, hTERT p53, BCL2, BAX, NRF2, HO-1, cyclins, and cyclin-dependent kinases) were quantified and analyzed. Cellular-myelocytomatosis (c-MYC) is an oncoprotein, controlling cell proliferation and lifespan extension [13]. It activates human telomerase reverse transcriptase (hTERT) transcription [14] and cell cycle progression [15]. The hTERT is a catalytic subunit of enzyme telomerase that maintains telomere length and cell immortality [16]. The p53 is a tumor suppressor protein involving cell cycle arrest, cell apoptosis, and ferroptosis [17]. The B-cell lymphoma 2 (BCL2) is an antiapoptotic protein that blocks programmed cell death to promote cell survival [18]. The BCL2 associated X protein (BAX) is a proapoptotic protein, inducing cell death [19]. The BCL2/BAX ratio is a rheostat that regulates cell death [20]. The nuclear transcription factor erythroid-2 related factor 2 (NRF2) influences a defense system against oxidative stress, such as heme oxygenase-1 (HO-1), an antioxidative enzyme [21]. In cancer cells, overexpression of NRF2 and HO-1 protected cancer cells from oxidative damage, promoting cancer cell proliferation and induced resistance to chemotherapeutic agents [22,23]. NRF2 also activated metalloproteinase, enhancing cancer cell invasion and metastasis [24]. Cyclin D1 with cyclindependent kinase (CDK)-4 control cell cycle transition from G0/G1 to S phase [25]. Cyclin D1 is an oncogene, controlling cell cycle regulation and chromosome stability [26]. Cyclin E1 regulates from G1 to early S phase [27], and cyclin B1 controls from G2 to M phase [28].

\section{Materials and methods}

\section{Cancer cell and chemicals}

Breast carcinoma cell line, MCF-7 (HB22) was purchased from American Type Culture Collection (ATCC), USA. 10-hydroxy-2-decenoic acid was purchased from Cayman Chemical Company, USA: CAS No. 14113-05-4, purity $98 \%$. Doxorubicin hydrochloride (Adriamycin) was purchased from Pfizer, U.S.A.

Determination of antiproliferative activities of 10H2DA and DXR by MTS tetrazolium assay

To determine cell viability, the CellTiter $96{ }^{\circledR}$ Aqueous One Solution Cell Proliferation MTS Assay Kit (Promega, USA) was used as described previously [29]. Briefly, the MCF-7 cells were seeded into 96-well plates at a density of 5,000 cells per well $(100 \mu \mathrm{L}$ medium $)$ for $24 \mathrm{~h}$. Cells were then treated with various concentrations of 10-H2DA $(0.0125,0.125,1.25,12.5$, and $125 \mu \mathrm{g} / \mathrm{mL})$ for $24 \mathrm{~h}$. Minimum Essential Medium Eagle (MEM) medium and doxorubicin (DXR) were used as negative and positive controls, respectively. Subsequently, $20 \mu \mathrm{L}$ of the 3-(4,5-dimethylthiazol-2-yl)-5-(3carboxymethoxyphenyl)-2-(4-sulfophenyl)-2H-tetrazolium (MTS) reagent was added to each well. The plates were incubated at $37{ }^{\circ} \mathrm{C}$ for $2 \mathrm{~h}$ in a $5 \% \mathrm{CO}_{2}$ incubator. Reduction of the MTS by viable cells generates colored formazan product. The absorbance at $490 \mathrm{~nm}$ was measured using a microplate spectrophotometer. The percentages of cell viability were calculated from the formula:

$\%$ cell viability $=[$ the absorbance of the treated well/the absorbance of the control well $] \times 100$

\section{Determination of cytotoxic activity by modified MTS tetrazolium assay}

In order to evaluate whether 10-H2DA could induce cytotoxic effect, we further determined fifty percent growth inhibition $\left(\mathrm{GI}_{50}\right)$, total growth inhibition (TGI), and $50 \%$ lethality $\left(\mathrm{LC}_{50}\right)$ of the $10-\mathrm{H} 2 \mathrm{DA}$ treatments against MCF-7 cells using modified MTS assay according to the protocol from the National Cancer Institute, USA [30]. Briefly, the MCF-7 cells were seeded in 96 well plates and cultured for $24 \mathrm{~h}$. 
After that, some of the plates are processed to determine cell growth at a time zero density. The remaining plates were treated with various concentrations of $10-\mathrm{H} 2 \mathrm{DA}(1.25,12.5,50,125$, and $250 \mu \mathrm{g} / \mathrm{mL})$ for 24 $\mathrm{h}$ and measured the percentage of cell growth compared to the time zero density. Growth percent of 100 corresponds to the growth seen in untreated cells. Growth percent of 50 corresponds to $50 \%$ inhibition $\left(\mathrm{GI}_{50}\right)$. Growth percent of 0 indicates no growth (TGI: total growth inhibition). Growth percent of -50 indicates lethality in $50 \%$ of the starting cells $\left(\mathrm{LC}_{50}\right)$. The percentages of cell growth were calculated from the following formula

$$
\begin{aligned}
\% \text { cell growth } & =\left[\left(\mathrm{T}-\mathrm{T}_{0}\right) / \mathrm{C}-\mathrm{T}_{0}\right] \times 100 \text { if } \mathrm{T} \geq \mathrm{T}_{0} \\
& \left.=\left[\mathrm{T}-\mathrm{T}_{0}\right) / \mathrm{T}_{0}\right] \times 100 \quad \text { if } \mathrm{T}<\mathrm{T}_{0}
\end{aligned}
$$

$\mathrm{T}_{0}=$ average absorbance of treated cells at $0 \mathrm{~h} ; \mathrm{T}=$ average absorbance of 10-H2DA-treated cells at $24 \mathrm{~h}$; $\mathrm{C}=$ average absorbance of medium-treated cells at $24 \mathrm{~h}$

\section{Analysis of cell cycle distribution and cell apoptosis by flow cytometry}

To determine cell cycle distribution, $1 \times 10^{5} \mathrm{MCF}-7$ cells were grown at $37{ }^{\circ} \mathrm{C}$ for $24 \mathrm{~h}$ in a $5 \% \mathrm{CO}_{2}$ incubator. Then, cells were treated with 10-H2DA $(1.25,12.5,125$, and $250 \mu \mathrm{g} / \mathrm{mL})$ for $24 \mathrm{~h}$. Subsequently, the cells were harvested, washed, and fixed with $70 \%$ cold ethanol overnight at $-20{ }^{\circ} \mathrm{C}$. Then, cells were collected and stained with propidium iodide (PI)/ribonuclease staining buffer (BD Biosciences, USA) for $20 \mathrm{~min}$ at room temperature. The cell cycle distribution was measured with Guava EasyCyteTM Flow Cytometer (Merck Millipore, USA) using GuavaSoft software [31].

To detect cell apoptosis, $1 \times 10^{5}$ MCF-7 cells were seeded into $25 \mathrm{~cm}^{2}$ flask overnight before treated with 10-H2DA $(1.25,12.5,125$ and $250 \mu \mathrm{g} / \mathrm{mL})$ for $24 \mathrm{~h}$. Harvested cells included a collection of floating cells and detached cells after trypsinization. Annexin V-FITC apoptosis detection kit I (BD Biosciences, USA) was applied as described by the manufacturer's instruction. Briefly, the treated cells were washed and incubated with FITC Annexin V and PI for $15 \mathrm{~min}$ in the dark at room temperature. The cells were analyzed immediately by Guava EasyCyteTM Flow Cytometer (Merck Millipore, USA). PI stains the dead cells as it permeates the damaged membrane. Annexin V and PI negatively stained cells mean viable cells. Annexin V positive and PI negative stained cells indicate early apoptosis with intact membrane. Annexin V and PI-positive stained cells show late apoptosis and cell death. Annexin V negative and PI positively stained cells demonstrate cell necrosis [31].

\section{Nuclear morphological changes detected by Hoechst33258/Propidium iodide double staining}

MCF-7 cells were seeded in tissue culture plates and treated with MEM medium, 1.25, 12.5, and $125 \mu \mathrm{g} / \mathrm{mL} 10-\mathrm{H} 2 \mathrm{DA}$ and $0.54 \mu \mathrm{g} / \mathrm{mL}$ DXR for $24 \mathrm{~h}$. After that, the treated cells were washed with cold PBS and stained with $10 \mu \mathrm{g} / \mathrm{mL}$ Hoechst 33258 solution for $7 \mathrm{~min}$ at $37^{\circ} \mathrm{C}$ in a $\mathrm{CO}_{2}$ incubator. The cells were then counterstained with PI $(2.5 \mu \mathrm{g} / \mathrm{mL})$ for $15 \mathrm{~min}$ in the dark at room temperature. The stained cells were immediately analyzed under a fluorescence microscope. Hoechst 33258 stained DNA in dark blue, and cells with apoptotic nuclei stained more brightly blue. PI stained DNA of the dead cells in red. When merging double staining color, dead cells with apoptotic nuclei stained bright blue with red apoptotic nuclei [32].

\section{Analysis of pivotal protein expressions by Western blot}

The treated cells were lysed with RIPA lysis buffer (Merck Millipore, USA) as previously described [33]. The boiled protein lysate was separated using $10 \%$ SDS-polyacrylamide gel electrophoresis, followed by blotting onto a nitrocellulose membrane (GE Healthcare, USA) and blocked with Odyssey blocking buffer (Li-COR, USA). Membranes were then probed with corresponding rabbit primary antibodies: anti-c-MYC, anti-p53, anti-BCL2, anti-BAX, anti-cyclin B1, anti-cyclin E1, and anti-CDK4 (Cell Signaling, USA); anti-hTERT, anti-HO-1, anti-NRF2, and anti-cyclin D1 (Merck Millipore, USA). Anti- $\beta$-actin polyclonal antibody (Cell Signaling, USA) was used as an internal control. After that, membranes were washed and incubated with LI-COR IRDye 680 mouse anti-rabbit. The protein bands were visualized using Odyssey FcImager (LI-COR, USA).

\section{Statistical analysis}

ANOVA with Dunnett's Post Hoc test was used to analyze the difference between the mean of the treated groups and the mean of the control group. Differences $p<0.05$ were considered statistically significant. 


\section{Results and discussion}

Antiproliferative activity of 10-H2DA against MCF-7 cells detected by MTS tetrazolium assay

Treatments with 10-H2DA only at $1.25,12.5$, and $125 \mu \mathrm{g} / \mathrm{mL}$ for $24 \mathrm{~h}$ significantly decreased MCF-7 cell viabilities in a dose-dependent manner to $78.3,62.5$, and $34.6 \%$, respectively, compared to MEM medium control $(\mathrm{p}<0.05)$ (Figure 1a). The lower doses at 0.0125 and $0.125 \mu \mathrm{g} / \mathrm{mL}$ did not significantly show antiproliferative activities. DXR treatment $(0.54 \mu \mathrm{g} / \mathrm{mL})$ significantly decreased cell viability to $52 \%$. The inhibition concentration (IC50) value derived from the log [10-H2DA] scale was $42.6 \mu \mathrm{g} / \mathrm{mL}$ (Figure 1b). Effects of 10-H2DA treatments on cell morphology (Figure 1c) corresponded with MTS assay results showing less cell survival (more damaged unattached rounded cells) when treated at higher concentrations of 10-H2DA.

(a)

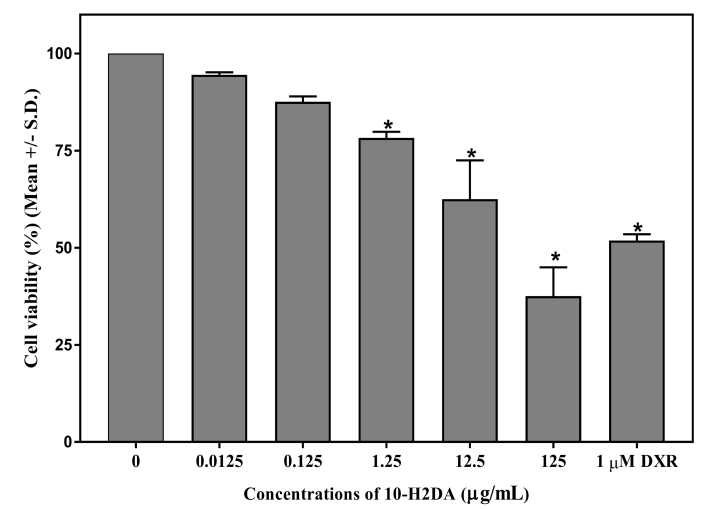

(c)
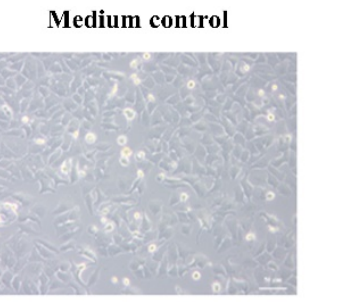

$12.5 \mu \mathrm{g} / \mathrm{mL} \mathrm{10-H2DA}$

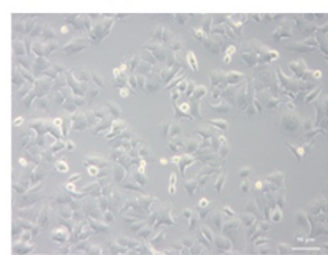

(b)

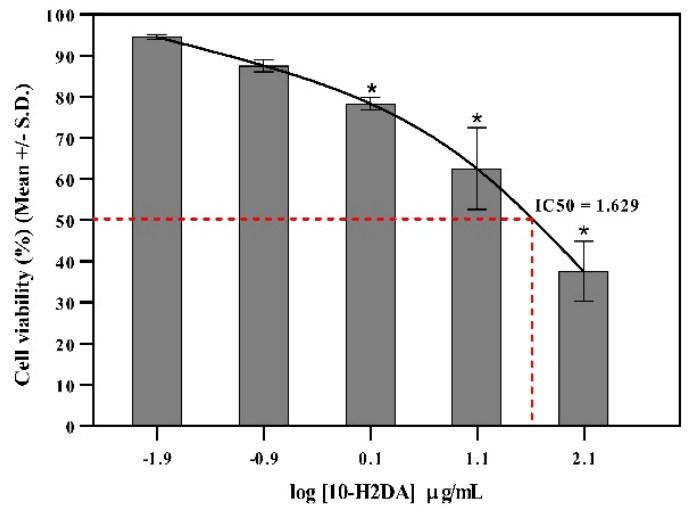

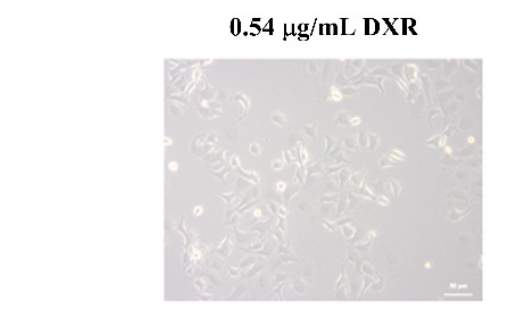

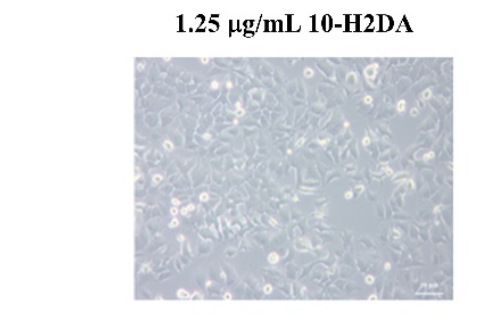

Figure 1 (a) The \% cell viability after various concentrations of 10-H2DA and DXR treatments on MCF7 breast cancer cells $(\mathrm{n}=3) ; * \mathrm{p}<0.05$ significantly different from the MEM medium control (b) Determination of IC50 value in $\log [10 \mathrm{H} 2 \mathrm{DA}]$ scale (c) MCF-7 cell morphology induced by medium control, $0.54 \mu \mathrm{g} / \mathrm{mL} \mathrm{DXR}$, and 10-H2DA treatments. 
Cytotoxic Activity of 10-H2DA treatments on MCF-7 cells detected by modified MTS tetrazolium assay

As shown in Figure 2a, the 10-H2DA treatments at $1.25,12.5,50,125$, and $250 \mu \mathrm{g} / \mathrm{mL}$ decreased $\%$ MCF-7 cell growth to $65.0,53.8,51.8,5.2$, and -92.6 , respectively, compared to the medium control at time zero density. The $\mathrm{GI}_{50}$, TGI, and $\mathrm{LC}_{50}$ values of $10-\mathrm{H} 2 \mathrm{DA}$ treatments were 55,132 , and $190 \mu \mathrm{g} / \mathrm{mL}$, respectively (Figure 2b). It is noteworthy that 10-H2DA treatments at concentrations between 12.5 to 55 $\mu \mathrm{g} / \mathrm{mL}$ inhibited cell growth at relatively similar levels and then increasingly inhibited when the concentrations increased. The data showed that 10-H2DA treatments induced cytotoxic effect on MCF-7 cells with $\mathrm{LC}_{50}$ at $190 \mu \mathrm{g} / \mathrm{mL}$.

(a)

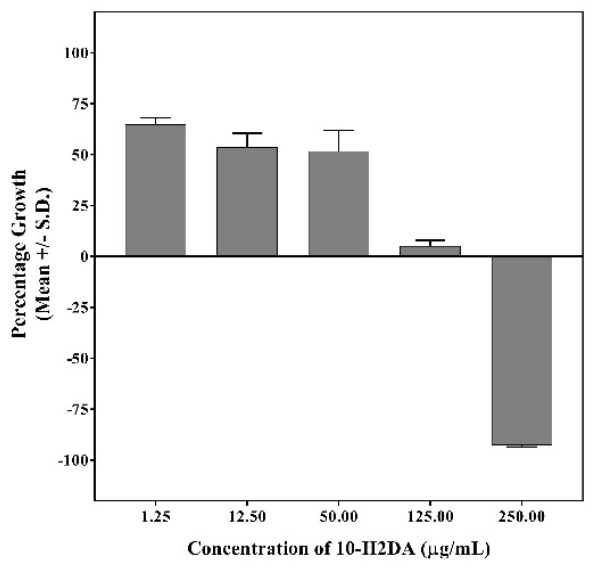

(b)

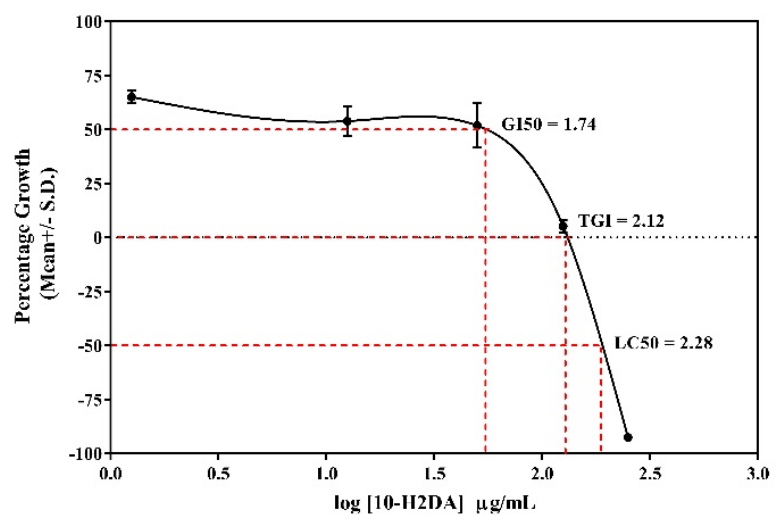

Figure 2 (a) The \% cell growth of various concentrations of 10-H2DA treatments on MCF-7 breast cancer cells $(\mathrm{n}=3) ; * \mathrm{p}<0.05$ significantly different from the MEM medium control (b) The GI50, TGI, and LC50 values of the 10-H2DA treatments on MCF-7 cells.

(a)

Medium Control

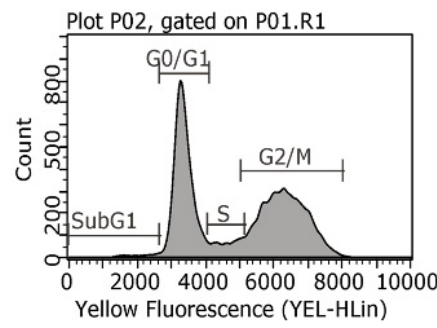

$125 \mu \mathrm{g} / \mathrm{mL}$ 10-H2DA

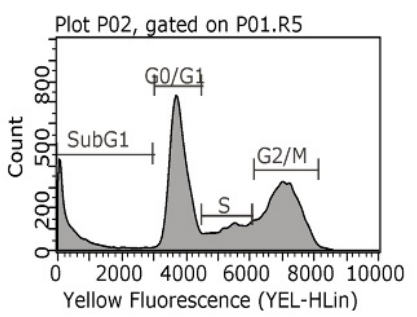

$1.25 \mu \mathrm{g} / \mathrm{mL} 10-\mathrm{H} 2 \mathrm{DA}$

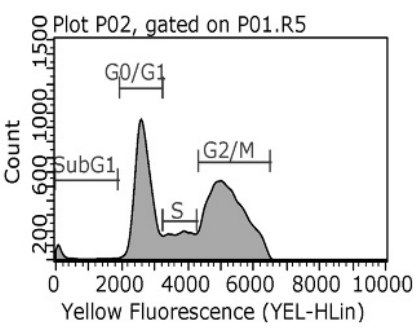

$250 \mu \mathrm{g} / \mathrm{mL} 10-\mathrm{H} 2 \mathrm{DA}$

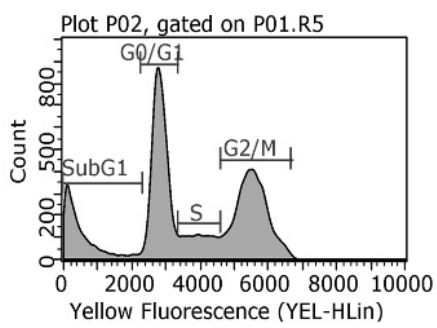

$12.5 \mu \mathrm{g} / \mathrm{mL} 10-\mathrm{H} 2 \mathrm{DA}$

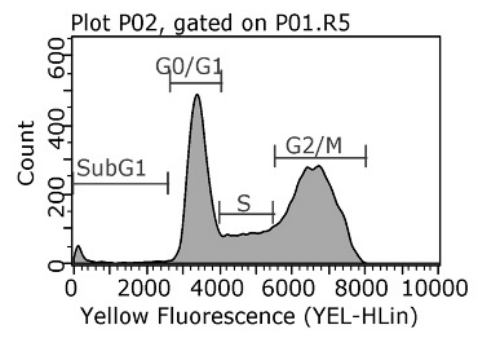

$0.54 \mu \mathrm{g} / \mathrm{mL}$ DXR

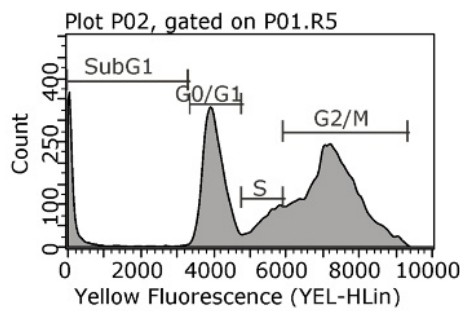


(b)

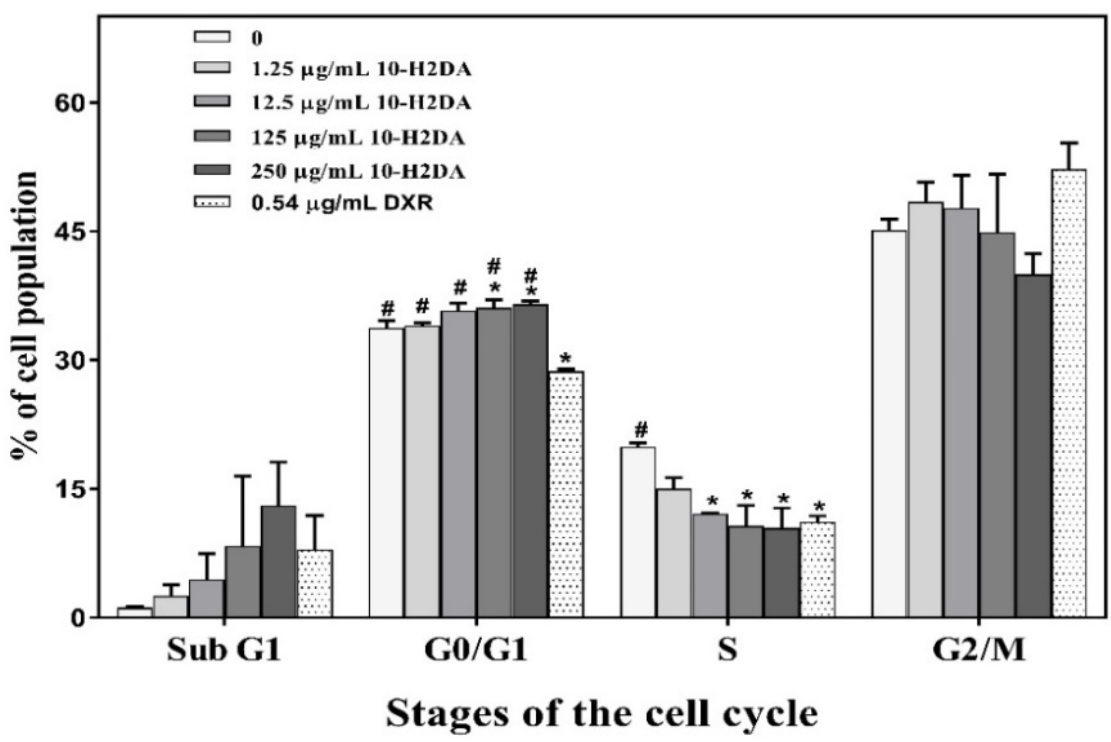

Figure 3 (a) Effects of 10-H2DA and DXR on cell cycle kinetics (b) the percentages of cell population in each phase of the cell cycle after exposure to 10-H2DA and DXR treatments for $24 \mathrm{~h}$, compared to MEM medium on MCF-7 cells (mean \pm S.E.) $(n=3) ; * p<0.05$ significantly different from the MEM medium control, ${ }^{\#} \mathrm{p}<0.05$ significantly different from the DXR control.

(a)

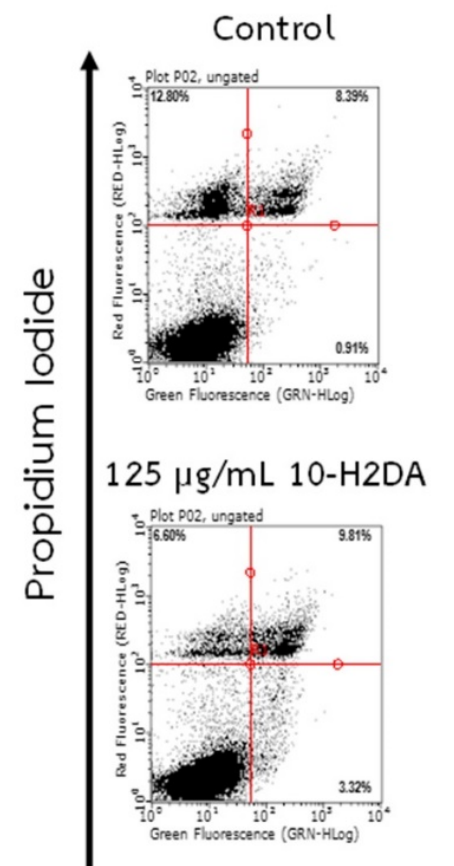

$1.25 \mu \mathrm{g} / \mathrm{mL} 10-\mathrm{H} 2 \mathrm{DA}$

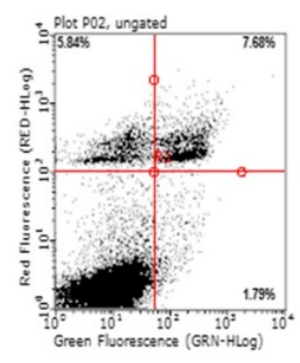

$250 \mu \mathrm{g} / \mathrm{mL} 10-\mathrm{H} 2 \mathrm{DA}$

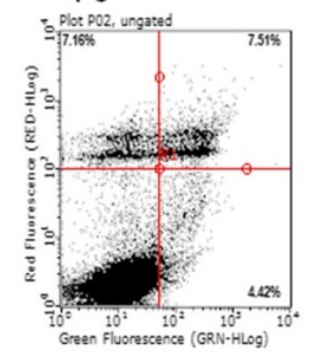

$12.5 \mu \mathrm{g} / \mathrm{mL} 10-\mathrm{H} 2 \mathrm{DA}$

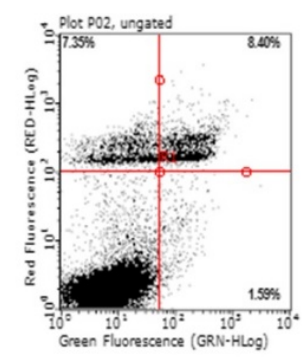

$0.54 \mu \mathrm{g} / \mathrm{mL} \mathrm{DXR}$

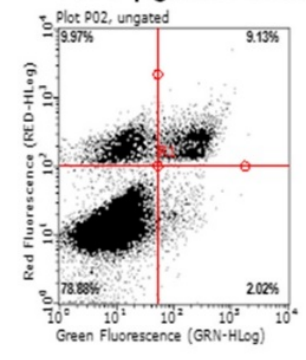

Annexin $\mathrm{V}$ 
(b)

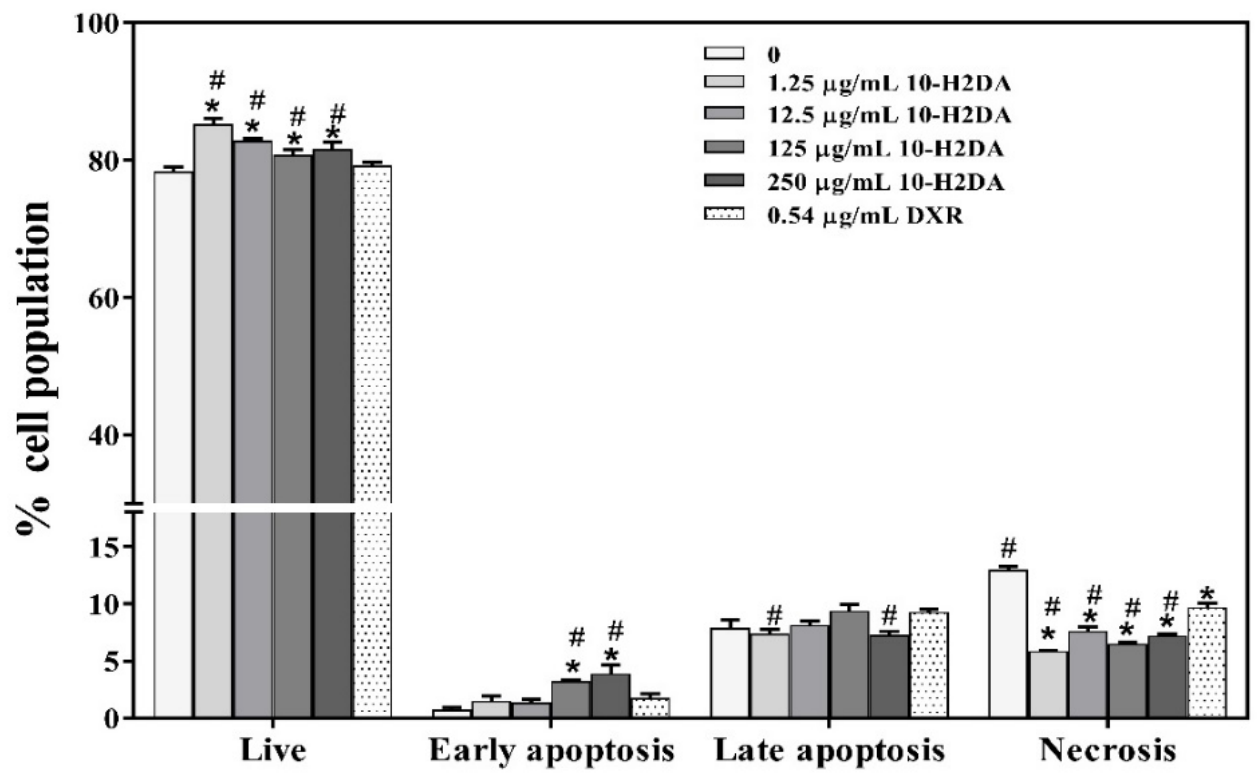

Figure 4 (a) Representative cell apoptosis of 10-H2DA and DXR treatments for $24 \mathrm{~h}$, compared to MEM medium on MCF-7 cells detected by flow cytometry using Annexin V-FITC apoptosis detection kit I (b) The percentages of live, early apoptotic, late apoptotic, and necrotic cells in response to all treatments. $(\mathrm{n}=3) * \mathrm{p}<0.05$ significantly different from the MEM medium control, ${ }^{\#} \mathrm{p}<0.05$ significantly different from the DXR control

Effects of 10-H2DA and DXR on cell cycle progression detected by flow cytometry

Results from flow cytometry (Figures 3a and 3b) showed that 10-H2DA at 125 and $250 \mu \mathrm{g} / \mathrm{mL}$ and $0.54 \mu \mathrm{g} / \mathrm{mL}$ DXR increased the percentages of cells in sub G1 to 1.6-, 2.4-, and 1.1-fold, respectively, suggesting induction of cell apoptosis. The 10-H2DA treatments increased the percentages of cells in G0/G1 phase, signifying induction of G0/G1 cell cycle arrest. The DXR treatment increased cells in the $\mathrm{G} 2 / \mathrm{M}$ phase, suggesting induction of G2/M cell cycle arrest.

\section{Effects of 10-H2DA and DXR on cell apoptosis detected by flow cytometry}

Results from flow cytometry (Figure $\mathbf{4 a}$ and $\mathbf{4 b}$ ) showed that treatments of 10-H2DA $(1.25,12.5$, 125 , and $250 \mu \mathrm{g} / \mathrm{mL}$ ) induced a dose-dependent increase in the percentages of early apoptotic cells (annexin V positive and PI negative) (2.0- to 4.8-fold) while decreasing the percentages of late apoptotic/necrotic cells (annexin V and PI-positive plus annexin V negative and PI-positive) (0.4-0.6fold). The DXR treatment increased the percentages of early apoptotic cells (2.2-fold) while decreasing those in the late apoptotic/necrotic phase (0.9-fold). These data confirm the induction of cell apoptosis induced by $10-\mathrm{H} 2 \mathrm{DA}$ and DXR treatments.

\section{Nuclear morphological changes detected by Hoechst 33258/PI double staining}

To recognize apoptotic cells from their characteristic morphological pattern, $125 \mu \mathrm{g} / \mathrm{mL} 10-\mathrm{H} 2 \mathrm{DA}$ and the DXR treatment alone showed a higher number of dead cells with apoptotic nuclei than the medium control (Figure 5). 


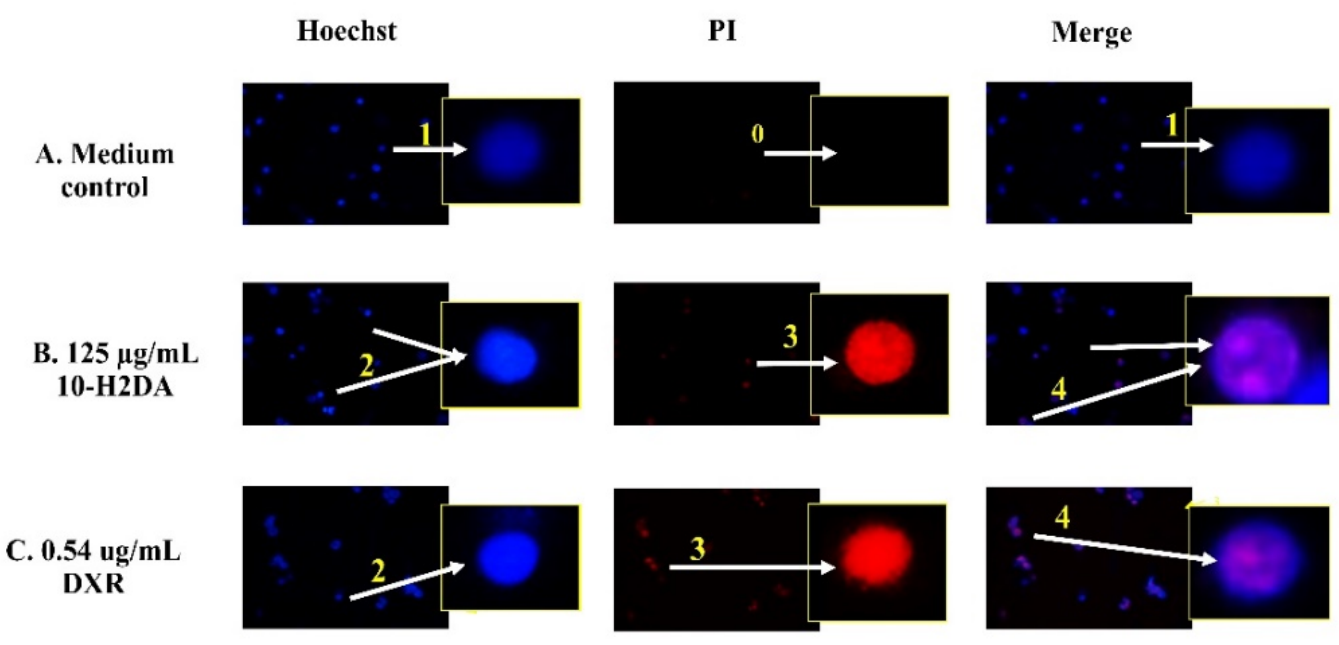

Figure 5 Representative photos of Hoechst 33258 and propidium iodide double staining of treated MCF7 breast cancer cells (A) medium control, (B) $125 \mu \mathrm{g} / \mathrm{mL} 10-\mathrm{H} 2 \mathrm{DA}$, (C) $0.54 \mu \mathrm{g} / \mathrm{mL}$ DXR; Arrows indicate (0) no dead cell (1) viable cells with normal nuclei, (2) live cells with apoptotic nuclei, (3) dead cells and (4) dead cells with apoptotic nuclei.

Effects of 10-H2DA and DXR on regulatory protein expressions detected by Western blot

Results from Western blot analysis (Figures 6a and 6b) showed that $125 \mu \mathrm{g} / \mathrm{mL} 10-\mathrm{H} 2 \mathrm{DA}$ treatments maximally decreased cyclin D1 (0.2-fold), CDK4 (0.2-fold), and cyclin B1 (0.5-fold) while slightly increasing cyclin E1 (1.1-fold). The DXR treatment decreased cyclin B1 (0.4-fold), followed by cyclin D1 (0.6-fold), CDK4 (0.8-fold), while increasing cyclin E1 (2.0-fold) levels. The data corresponded with flow cytometry results that $125 \mu \mathrm{g} / \mathrm{mL} 10-\mathrm{H} 2 \mathrm{DA}$ treatment induced G0/G1 cell cycle arrest (mainly decreased cyclin D1 and CDK4) while the DXR treatment induced G2/M phase cell cycle arrest (mainly decreased cyclin B1).

(a)

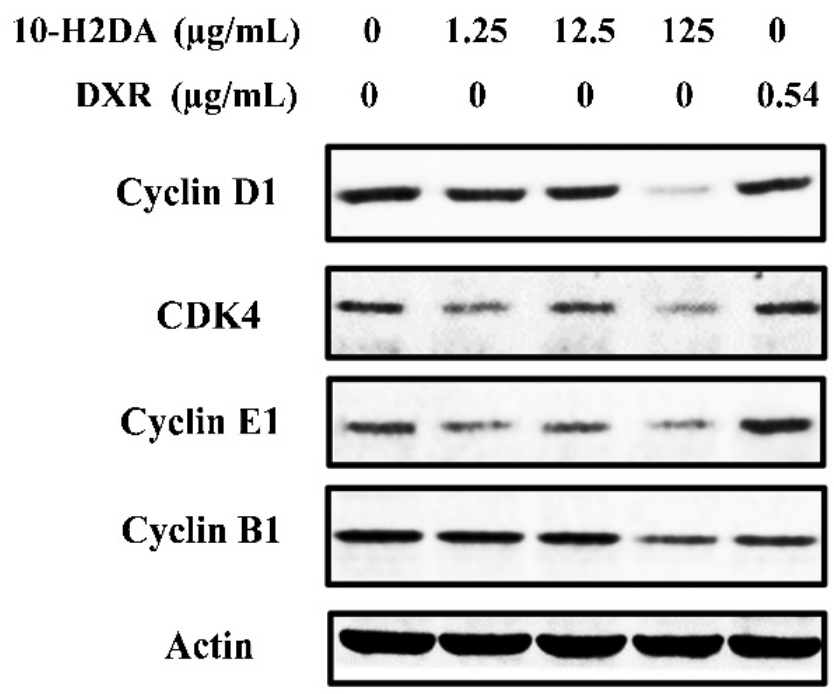


(b)

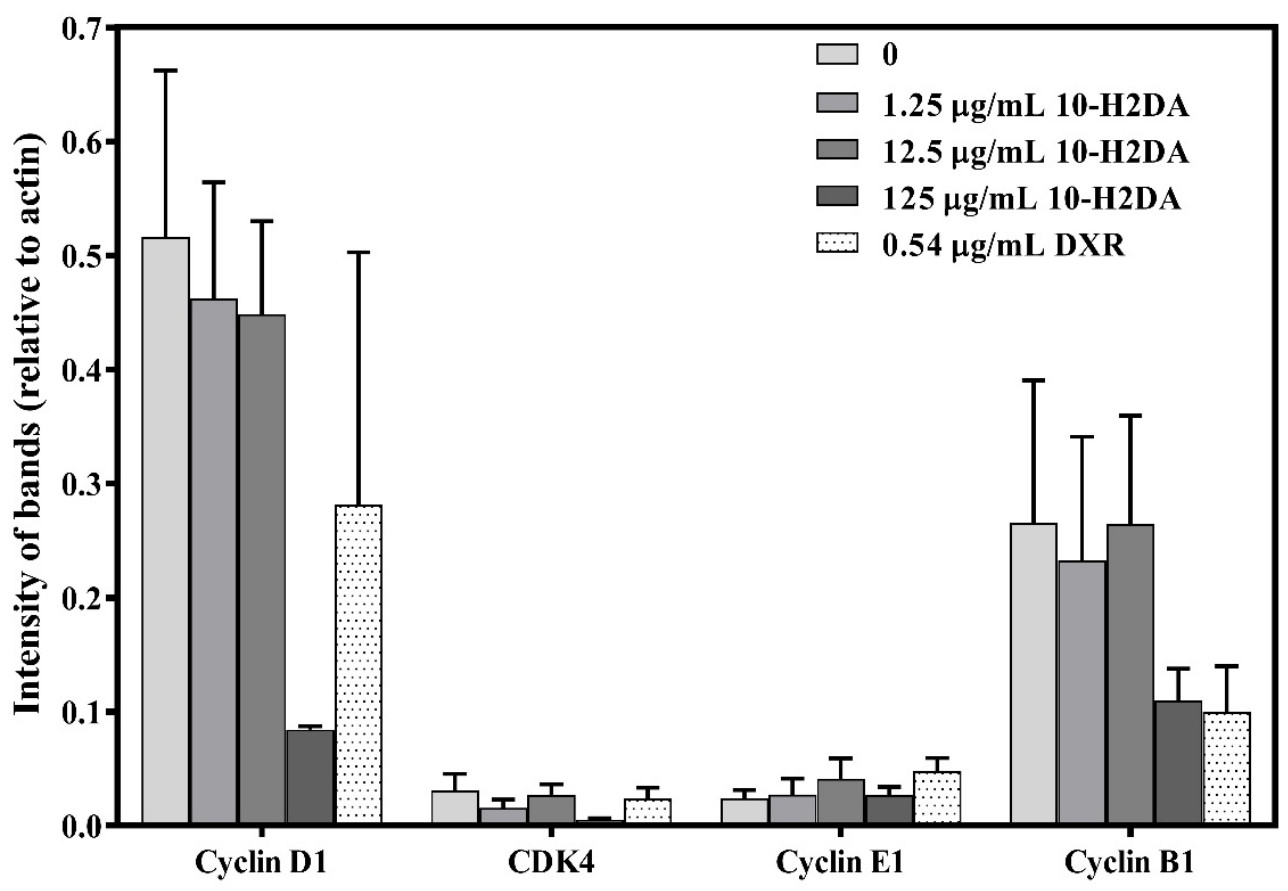

(C)

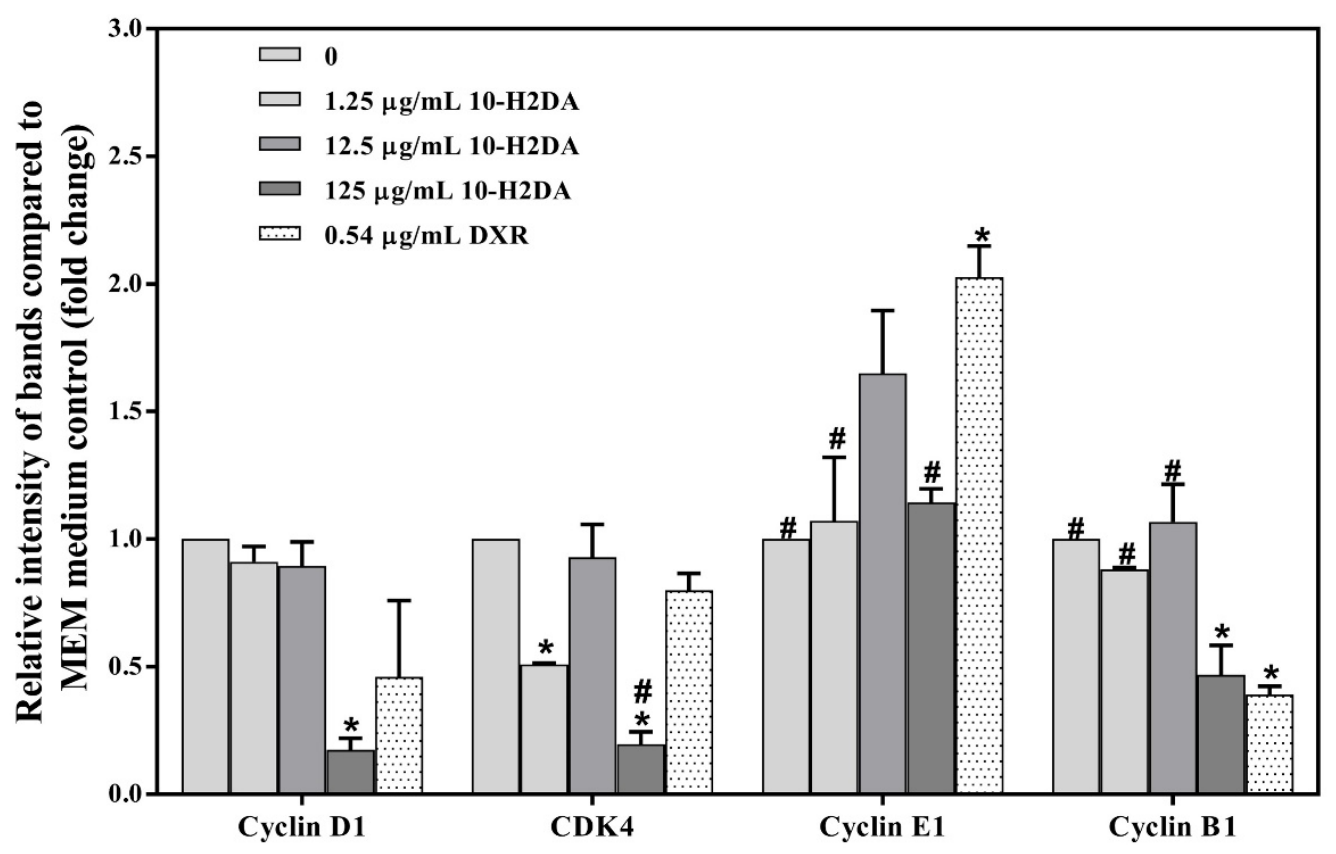

Figure 6 Effects of 10-H2DA and DXR treatments on protein expression of cell cycle regulators detected Western blot (a) Representative Western blot analysis, (b) Relative intensity of bands (fold change) and (c) Relative expression level of cyclin D1, CDK4, cyclin E1, and cyclin B1 (mean $\pm \mathrm{SE}$ ) in response to 10 -H2DA and DXR treatments for $24 \mathrm{~h}$ in MCF-7 cells $(n=3) ;{ }^{*} p<0.05$ significantly different from the MEM medium control, ${ }^{\#} \mathrm{p}<0.05$ significantly different from the DXR. 
As shown in Figures 7a and 7b, 10-H2DA treatment at $125 \mu \mathrm{g} / \mathrm{mL}$ decreased the levels of c-MYC, BCL2, h-TERT, BAX, p53, while extensively increasing HO-1 and NRF2 levels. As in our previous publication $[33,34]$, we showed the protein expression levels in a relationship with BAX: c-MYC/BAX, BCL2/BAX, h-TERT/BAX, p53/BAX, HO-1/BAX, and NRF2/BAX (Figure 7c). Such evaluation reflects survival and death in treated cells similar to BCL2/BAX, rheostat regulating life and death [20]. Alternatively, the BAX level served as an internal control to compare different levels of regulatory proteins. Results demonstrated that $125 \mu \mathrm{g} / \mathrm{mL} 10-\mathrm{H} 2 \mathrm{DA}$ treatment decreased cell proliferation mainly via extensively decreased C-MYC/BAX (0.2-fold) and slightly increased p53/BAX (1.1-fold). It increased cell apoptosis via decreased BCL2/BAX (0.6-fold) and slightly decreased lifespan extension via decreased hTERT/BAX (0.9-fold). It also extensively increased antioxidative power via increased NRF2/BAX (3.9-fold) and HO-1/BAX (37.1-fold). These data indicated that $125 \mathrm{ug} / \mathrm{mL} 10-\mathrm{H} 2 \mathrm{DA}$ effectively inhibited cell proliferation, induced cell cycle arrest (mainly G0/G1 phase), and induced cell apoptosis. Induction of NRF2/BAX and $\mathrm{HO}-1 / \mathrm{BAX}$ possibly increased cancer invasiveness and chemoresistance.

The DXR treatment $(0.54 \mu \mathrm{g} / \mathrm{mL})$ decreased cell proliferation via extensively decreased cMYC/BAX (0.2-fold) and increased p53/BAX (18.9-fold). It effectively increased cell apoptosis via decreased BCL2/BAX (0.3-fold) and limited lifespan extension via decreased hTERT/BAX (0.1-fold). Compared to the $125 \mu \mathrm{g} / \mathrm{mL} 10-\mathrm{H} 2 \mathrm{DA}$, the DXR treatment increased cell apoptosis and limited lifespan extension more effectively. Additionally, it suppressed NRF2/BAX (0.4-fold) while increasing HO1/BAX (1.8-fold) and p53/BAX (18.9-fold), possibly involving cell ferroptosis, another type of cell death. Nevertheless, $125 \mu \mathrm{g} / \mathrm{mL} 10-\mathrm{H} 2 \mathrm{DA}$ treatment suppressed c-MYC, cyclin D1, and CDK4 more aggressively than the DXR.

(a)

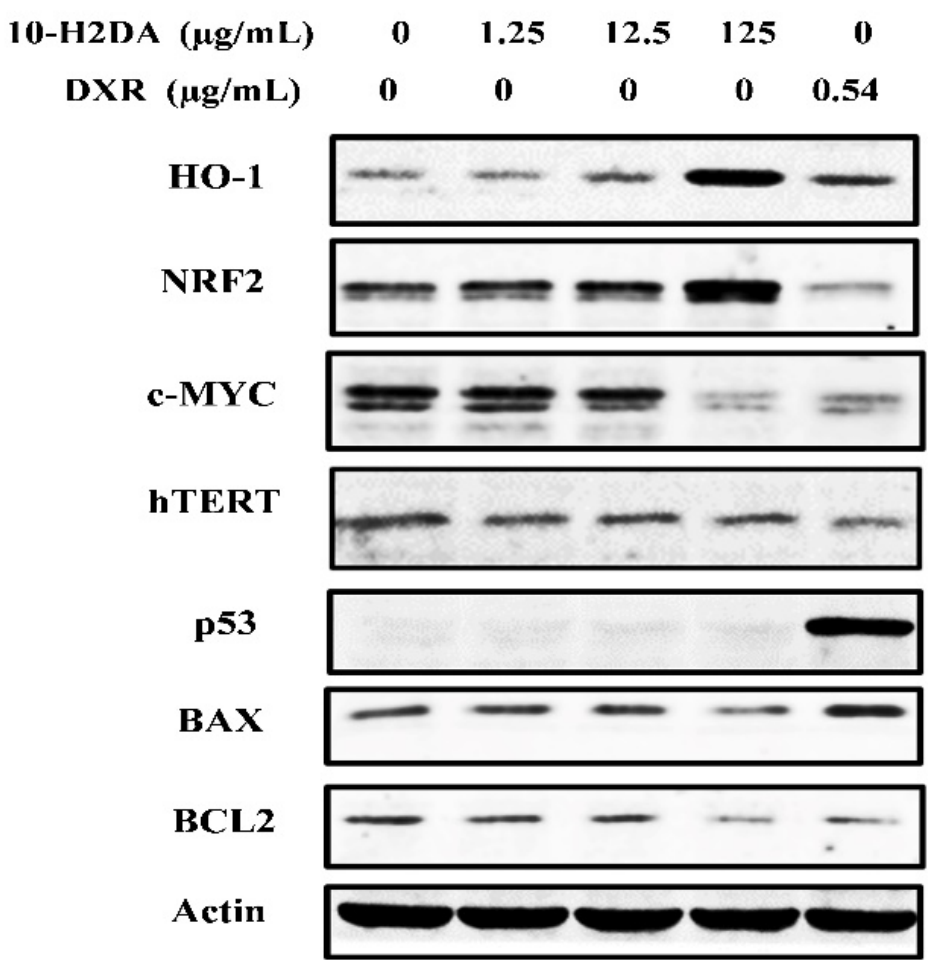


(b)

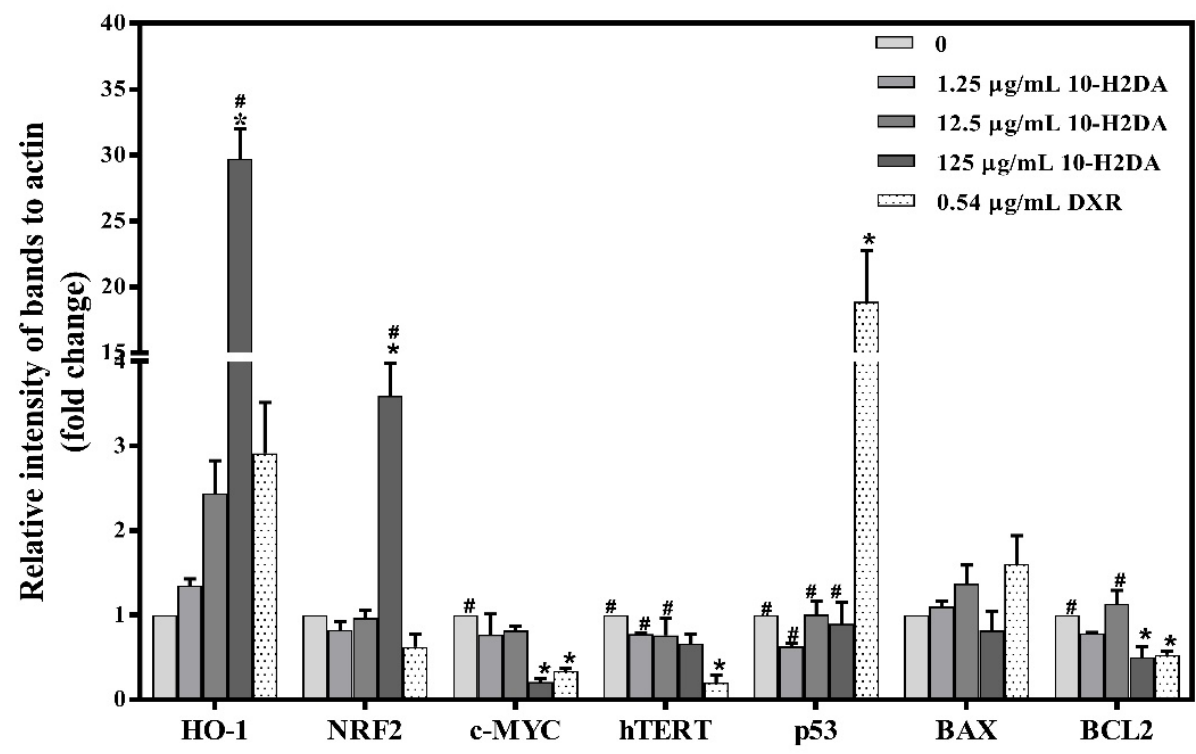

(c)

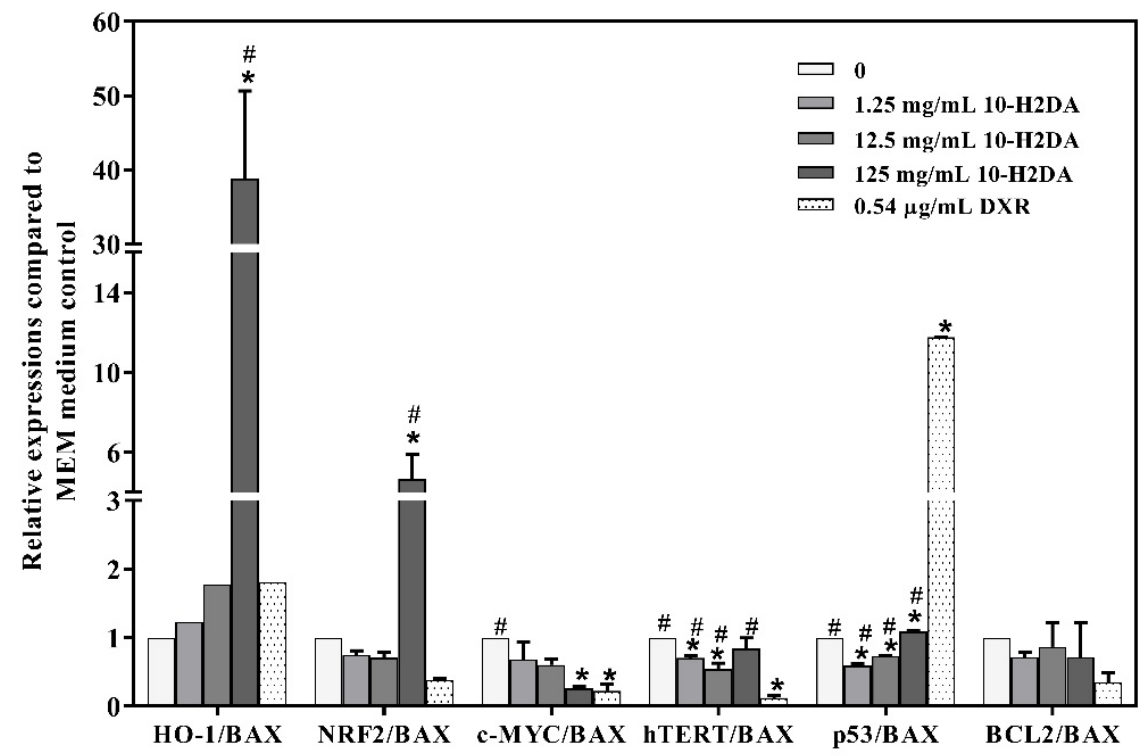

Figure 7 Effects of 10-H2DA and DXR treatments on regulatory protein expressions detected Western blot (a) Representative Western blot, (b) Relative protein expression levels of HO-1, NRF2, C-MYC, hTERT, p53, BAX, and BCL2 in response to various concentrations of $10-\mathrm{H} 2 \mathrm{DA}$ and $0.54 \mu \mathrm{g} / \mathrm{mL}$ DXR treatments on MCF-7 cells (mean $\pm \mathrm{SE})(\mathrm{n}=3)$ (c) Relative protein expression levels over BAX, compared to the medium control; ${ }^{*} \mathrm{p}<0.05$ significantly different from the MEM medium control, ${ }^{\#} \mathrm{p}<$ 0.05 significantly different from the DXR.

Taken together, our result demonstrated that antiproliferative and cytotoxic activities of $125 \mu \mathrm{g} / \mathrm{mL}$ 10-H2DA treatment effectively inhibited MCF-7 cell growth at a higher level than $0.54 \mu \mathrm{g} / \mathrm{mL}$ DXR. Its underlying mechanisms revealed that the 10-H2DA treatment extensively suppressed cell proliferation via decreased oncoprotein c-MYC/BAX. It induced G0/G1 cell cycle arrest via decreased cyclin D1 and CDK4. Additionally, it increased tumor suppressor protein p53/BAX, leading to induction of cell apoptosis (decreased BCL2/BAX). These findings revealed the underlying molecular antitumor mechanisms induced by $10-\mathrm{H} 2 \mathrm{DA}$, supporting a previous in vivo study showing that $10-\mathrm{H} 2 \mathrm{DA}$ has 
antitumor activities in transplanted mice [4]. However, the data also demonstrated that 10-H2DA treatment extensively increased antioxidative power via increased HO-1/BAX and NRF2/BAX. Overexpression of HO-1 and NRF-2 protects cancer cells from oxidative damage, leading to cancer cell resistance to chemotherapy and cancer cell invasion [24,35]. Therefore, the limitation of the 10-H2DA treatment is that it possibly induces chemoresistance if it is used in the long term. The proposed inhibitory mechanisms of the $125 \mu \mathrm{g} / \mathrm{mL} 10-\mathrm{H} 2 \mathrm{DA}$ treatment on MCF-7 breast cancer cells are summarized in Figure 8.

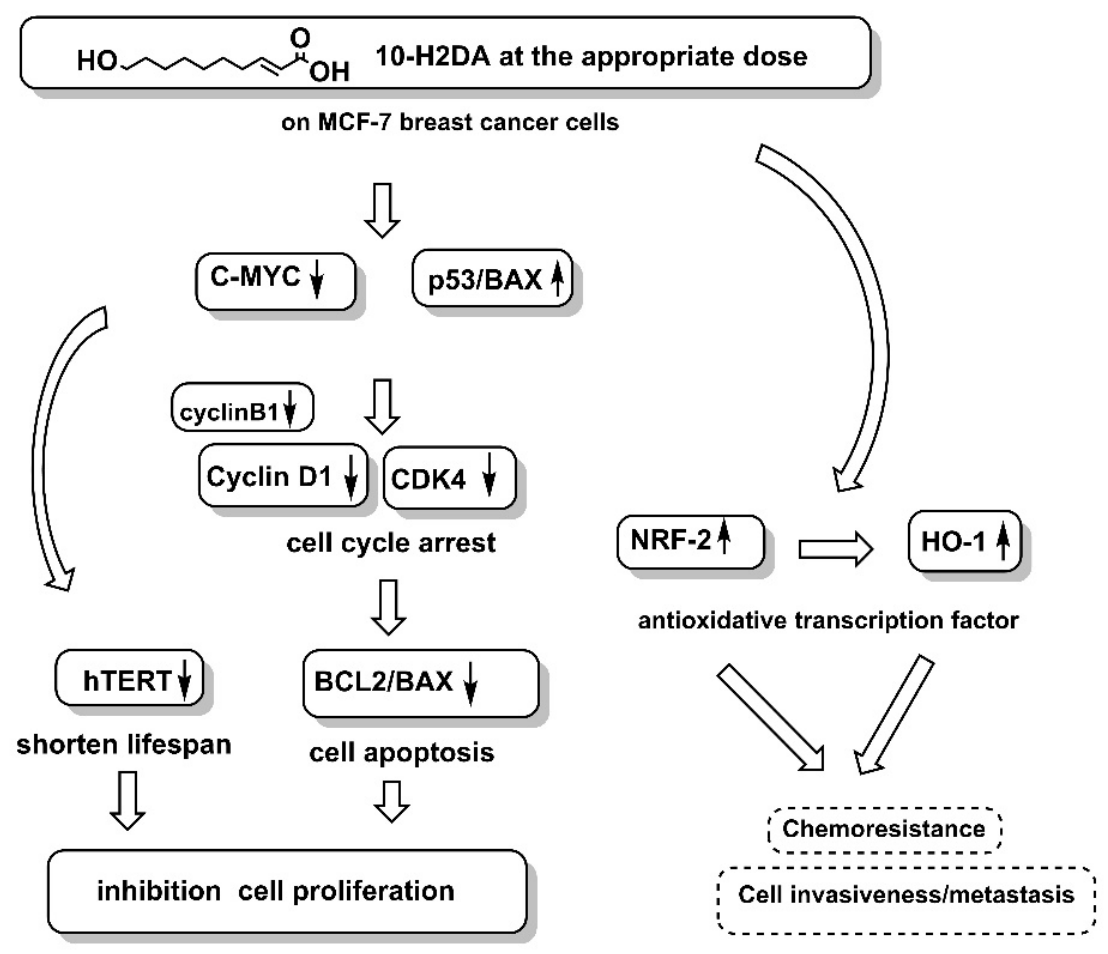

Figure 8 Summarized molecular mechanisms underlying antiproliferative and cytotoxic effects of 10H2DA treatment on MCF-7 breast cancer cells showing suppression of oncoprotein, c-MYC/BAX, induction of tumor suppressor, p53/BAX, leading to cell cycle arrest, cell apoptosis, and limiting lifespan extension. Activation of NRF2/BAX and HO-1/BAX potentially increased chemoresistance and cancer invasion later on.

\section{Conclusions}

Treatment of 10-H2DA at a proper dose is a promising candidate for breast cancer treatment. It is a powerful antiproliferative agent but should be used aggressively in a short period to prevent chemoresistance and cancer invasion later. Further in vitro and in vivo mechanistic studies for a long-term period would be helpful to validate their benefits and weakness.

\section{Acknowledgements}

The authors gratefully appreciate Prof. Dr. William W. Au for his criticism and valuable advice. Special thanks to Debra Kim Liwiski and Michael Everts for their careful assistance in editing this paper. The authors gratefully acknowledge the financial support provided by Thammasat University Research Fund, under the TU Research Scholar, Contract No. TUFT 16/2562, Thailand. 


\section{References}

[1] F Bray, J Ferlay, I Soerjomataram, RL Siegel, LA Torre and A Jemal. Global cancer statistics 2018: GLOBOCAN estimates of incidence and mortality worldwide for 36 cancers in 185 countries. $C A$ Canc. J. Clin. 2018; 68, 394-424.

[2] D Hanahan and RA Weinberg. The hallmarks of cancer. Cell 2000; 100, 57-70.

[3] ML Tan, PFM Choong and CR Dass. Review: Doxorubicin delivery systems based on chitosan for cancer therapy. J. Pharm. Pharmacol. 2009; 61, 131-42.

[4] GF Townsend, JF Morgan, S Tolnai, B Hazlett, HJ Morton and RW Shuel. Studies on the in vitro antitumor activity of fatty acids. I. 10-Hydroxy-2-decenoic acid from royal jelly. Canc. Res. 1960; 20, 503-10.

[5] F Fratini, G Cilia, S Mancini and A Felicioli. Royal Jelly: An ancient remedy with remarkable antibacterial properties. Microbiol. Res. 2016; 192, 130-41.

[6] YC Yang, WM Chou, DA Widowati, IP Lin and CC Peng. 10-hydroxy-2-decenoic acid of royal jelly exhibits bactericide and anti-inflammatory activity in human colon cancer cells. BMC Compl. Alternative Med. 2018; 18, 202.

[7] Y Honda, Y Fujita, H Maruyama, Y Araki, K Ichihara, A Sato, T Kojima, M Tanaka, Y Nozawa, M Ito and S Honda. Lifespan-extending effects of royal jelly and its related substances on the nematode Caenorhabditis elegans. PLoS One 2011; 6, e23527.

[8] C Bincoletto, S Eberlin, CAV Figueiredo, MB Luengo and MLS Queiroz. Effects produced by royal jelly on haematopoiesis: relation with host resistance against Ehrlich ascites tumour challenge. Int. Immunopharmacol. 2005; 5, 679-88.

[9] Y Miyata, K Araki, K Ohba, T Mastuo, Y Nakamura, T Yuno, Y Mukai, A Otsubo, K Mitsunari, Y Mochizuki and H Sakai. Oral intake of royal jelly improves anti-cancer effects and suppresses adverse events of molecular targeted therapy by regulating TNF-alpha and TGF-beta in renal cell carcinoma: A preliminary study based on a randomized double-blind clinical trial. Mol. Clin. Oncol. 2020; 13, 29.

[10] S Pengpanich, D Srisupabh and WU Tanechpongtamb. Potential role of royal jelly and 10-hydroxy2-decenoic acid as metastasis inhibitors in triple-negative breast cancer cells. J. Med. Assoc. Thailand 2019; 102, 7-24.

[11] M Nakaya, H Onda, K Sasaki, A Yukiyoshi, H Tachibana and K Yamada. Effect of royal jelly on bisphenol A-induced proliferation of human breast cancer cells. Biosci. Biotechnol. Biochem. 2007; 71, 253-5.

[12] DA Gewirtz. A critical evaluation of the mechanisms of action proposed for the antitumor effects of the anthracycline antibiotics adriamycin and daunorubicin. Biochem. Pharmacol. 1999; 57, 727-41.

[13] DM Miller, SD Thomas, A Islam, D Muench and K Sedoris. c-Myc and cancer metabolism. Clin. Canc. Res. 2012; 18, 5546-53.

[14] KJ Wu, C Grandori, M Amacker, N Simon-Vermot, A Polack, J Lingner and R Dalla-Favera. Direct activation of TERT transcription by c-MYC. Nat. Genet. 1999; 21, 220-4.

[15] JI Daksis, RY Lu, LM Facchini, WW Marhin and LJ. Penn. Myc induces cyclin D1 expression in the absence of de novo protein synthesis and links mitogen-stimulated signal transduction to the cell cycle. Oncogene 1994; 9, 3635-45.

[16] CW Greider. Telomerase activation. One step on the road to cancer? Trends Genet. 1999; 15,10912.

[17] L Jiang, N Kon, T Li, SJ Wang, T Su, H Hibshoosh, R Baer and W Gu. Ferroptosis as a p53mediated activity during tumour suppression. Nature 2015; 520, 57-62.

[18] J Yuan, H Lan, X Jiang, D Zeng and S Xiao. Bcl2 family: Novel insight into individualized therapy for ovarian cancer (Review). Int. J. Mol. Med. 2020; 46, 1255-65.

[19] ME Maes, CL Schlamp, RW Nickells. Live-cell imaging to measure BAX recruitment kinetics to mitochondria during apoptosis. PLoS One 2017; 12, e0184434.

[20] SJ Korsmeyer, JR Shutter, DJ Veis, DE Merry and ZN Oltvai. Bcl-2/Bax: A rheostat that regulates an anti-oxidant pathway and cell death. Semin. Canc. Biol. 1993; 4, 327-32.

[21] JD Hayes and AT Dinkova-Kostova. The Nrf2 regulatory network provides an interface between redox and intermediary metabolism. Trends Biochem. Sci. 2014; 39, 199-218.

[22] MC Jaramillo and DD Zhang. The emerging role of the Nrf2-Keap1 signaling pathway in cancer. Gene. Dev. 2013; 27, 2179-91. 
[23] N Tracey, H Creedon, AJ Kemp, J Culley, M Muir, T Klinowska and VG Brunton. HO-1 drives autophagy as a mechanism of resistance against HER2-targeted therapies. Breast Canc. Res. Treat. 2020; 179, 543-55.

[24] H Shen, Y Yang, S Xia, B Rao, J Zhang and J Wang. Blockage of Nrf2 suppresses the migration and invasion of esophageal squamous cell carcinoma cells in hypoxic microenvironment. Dis. Esophagus 2014; 27, 685-92.

[25] P Dong, C Zhang, BT Parker, L You and B Mathey-Prevot. Cyclin D/CDK4/6 activity controls G1 length in mammalian cells. PLoS One 2018; 13, e0185637.

[26] G Tchakarska and B Sola. The double dealing of cyclin D1. Cell Cycle 2020; 19, 163-78.

[27] W Jiang, H Huang, L Ding, P Zhu, H Saiyin, G Ji, J Zuo, D Han, Y Pan, D Ding, X Ma, Y Zhang, J Wu, Q Yi, JO Liu, H Huang, Y Dang and L Yu. Regulation of cell cycle of hepatocellular carcinoma by NF90 through modulation of cyclin E1 mRNA stability. Oncogene 2015; 34, 4460-70.

[28] B Strauss, A Harrison, PA Coelho, K Yata, M Zernicka-Goetz and J Pines. Cyclin B1 is essential for mitosis in mouse embryos, and its nuclear export sets the time for mitosis. J. Cell. Biol. 2018; 217, 179-93.

[29] AL Niles, RA Moravec and TL Riss. Update on in vitro cytotoxicity assays for drug development. Expet. Opin. Drug Discov. 2008; 3, 655-69.

[30] SL Holbeck. Update on NCI in vitro drug screen utilities. Eur. J. Canc. 2004; 40, 785-93.

[31] M Lenzi, M Malaguti, V Cocchi, S Hrelia and P. Hrelia. Castanea sativa Mill. bark extract exhibits chemopreventive properties triggering extrinsic apoptotic pathway in Jurkat cells. BMC Compl. Alternative Med. 2017; 17, 251.

[32] SNSA Rahman, NAWahab and SNA Malek. In Vitro Morphological Assessment of Apoptosis Induced by Antiproliferative Constituents from the Rhizomes of Curcuma zedoaria. Evid. Base. Compl. Alternative Med. 2013; 2013, 257108.

[33] W Jenkhetkan, S Thitiorul, C Jansom and T Ratanavalachai. Molecular and cytogenetic effects of Thai royal jelly: modulation through c-MYC, h-TERT, NRF2, HO-1, BCL2, BAX and cyclins in human lymphocytes in vitro. Mutagenesis 2017; 32, 525-31.

[34] W Jenkhetkan, S Thitiorul, C Jansom and T Ratanavalachai. Genoprotective effects of Thai royal jelly against doxorubicin in human lymphocytes in vitro. Nat. Product Comm. 2018; 13, 79-84.

[35] XJ Wang, Z Sun, NF Villeneuve, S Zhang, F Zhao, Y Li, W Chen, X Yi, W Zheng, GT Wondrak, PK Wong and DD Zhang. Nrf2 enhances resistance of cancer cells to chemotherapeutic drugs, the dark side of Nrf2. Carcinogenesis 2008; 29, 1235-43. 